\title{
Peumulia Jamee Culture and the Stage of Building Rapport in Individual Counseling Process
}

\author{
Zahra Nelissa* \\ Bimbingan dan Konseling \\ FKIP Universitas Syiah Kuala \\ Banda Aceh, Indonesia \\ zahranelissa@unsyiah.ac.id*
}

\author{
Fitra Marsela \\ Bimbingan dan Konseling \\ FKIP Universitas Syiah Kuala \\ Banda Aceh, Indonesia \\ fitramarsela.fm@gmail.com
}

\author{
Syaiful Bahri \\ Bimbingan dan Konseling \\ FKIP Universitas Syiah Kuala \\ Banda Aceh, Indonesia \\ saifulnani@yahoo.com
}

\author{
Mifta Oktavianda \\ Bimbingan dan Konseling \\ FKIP Universitas Syiah Kuala \\ Banda Aceh, Indonesia \\ mifta.oktavianda@gmail.com
}

\author{
M. Husen \\ Bimbingan dan Konseling \\ FKIP Universitas Syiah Kuala \\ Banda Aceh, Indonesia \\ m.husen57@unsyiah.ac.id
}

\begin{abstract}
Aceh has a culture and customs that are closely aligned to Islamic rules. Of the various customs and cultures that exist in Aceh, one notable custom is the glorification of guests (peumulia jame). Its origin comes from the viewpoint in Islam concerned with glorifying guests, which for a Muslim who believes in Allah and the end of the day, is mandatory. This study aims to apply peumulia jamee in order to build rapport in the individual psychology counseling process and determine the effectiveness of glorifying guests in the process of building rapport in individual counseling. This research uses a descriptive method, which is a method of analyzing and describing existing research data, which are associated with theories related to the problem that needs to be solved, in order to draw a conclusion. This research was carried out around the city of Banda Aceh. The data was collected though interview and observation. The number of samples used in this study was ten people. In this study, the data collection consisted of primary data and secondary data. Based on conclusions from the interviews, the respondents mainly apply the culture peumulia jame when building rapport cards in the process of counseling. This is because the culture of peumulia jame has been 'ingrained' in Acehnese society.
\end{abstract}

Keywords - application of Pemulia Jamee, building rapport, individual counseling

\section{INTRODUCTION}

The era of globalization, often being synonymous with competition and the development of individual competencies, must also be balanced with healthy and resilient mental development. Today, the problems faced by people in a country are very diverse, ranging from personal, social, family, cultural, health, and economic problems. The inability of individuals to solve their problems leads to the complication of those problems. This phenomenon suggests that there is a need for help from professionals to intervene in order to solve the problem. Historically, the people of Aceh have very diverse socio-cultural conditions and have a lot of stories that date back centuries, such as the history of the glory of Aceh, the history of conflicts that have occurred in Aceh, and also the history of natural disasters that have occurred in the province, which is known to have the nickname Serambi Mekkah, or the threshold of Mecca. Because of Aceh's tumultuous history, it may need more attention on mental health and improving the quality of life for its residents, in order to compete healthily in this era of globalization. Before solving community problems related to culture and social psychological, it should be noted that human resources, like counselors, should take culture into account when carrying out individual counseling. The development of a competent counselor should be done in a comprehensive, culturally sensitive, and sustainable way.

The general overview of the process of individual counseling is divided into three stages: the initial stage begins when the client meets with the counselor and the client attempts to define and find the source of their problem. Second, the middle stage, departs from the definition of the client's problem, which was determined in the initial stage. The next activity focuses on exploring the client's problem and what assistance will be given, based on an assessment of that problem. The third and final stage, it is marked by several things, namely: (1) Decreased client anxiety. This can be known after the counselor asks about their anxiety condition; (2) There is a change in client behavior in a more positive direction, including future life plans with a clear program; (3) The occurrence of a positive attitude, which can correct the client's self and leave behind the attitude that tends to blame others, such as parents, friends, teachers, circumstances, and so forth. Thus, after these steps, the client can think realistically and confidently [1].

Peumulia Jamee is a source of great happiness for Acehnese people when a guest arrives. Because of this, guests are very glorified and received with great respect. In Acehnese society, this custom is known as peumulia jamee, meaning to glorify guests [2]. The custom is not new. This saying is very down to earth in Tanah Rencong. Since ancient times, Aceh has been known as an open kingdom which highly respects guests. The Malay proverb that guests 
is the king is applied by the people of Aceh [3]. Peumulia Jamee adat Geutanyoe is a tradition that is very popular today for the people of Aceh. This saying means glorifying guests, our custom which is have been very ingrained in the Land of Rencong. Since ancient times, Aceh has been known as an open kingdom and highly respects guests [4].

The relationship between counseling and culture is classified into three foundations. First, counseling is a cultural product. Second, counseling is a producer of culture. Third, counseling is a forum for cultural encounters. The first dimension is part of the study of the Socio-Cultural Foundation of Guidance and Counseling. Culture encourages the birth and development of counseling. This is a positive review. There is also a negative review of the effect of socio-cultural developments on the development of counseling services [5].

Many cultural behaviors are involved in counseling relationships and effect the efficacy of counseling. However, one thing that hasn't been realized is how important nonverbal languages are in certain cultures. Cultural expression comes not only in the form of verbal communication, but in non-verbal language as well. Many cultures are classified as "high-context cultures" (Hofstede, 1990), including Indonesia and non-Western countries in general, and non-verbal languages are even more important than verbal languages [6].

Rapport and individual counseling stages in the counseling process, a counselor must be able to involve the counselee in full, so that the counselee can be open. Counselors are required to be able to communicate effectively. Good counseling will be achieved if the counselor has good communication skills. Attending is the first and main step in the counseling process, because this will have an impact on the counselee in providing information to the counselor and the emergence of trust between counselor and counselee [7].

The counseling process is carried out through five stages, the delivery stage (introduction), the assessment stage (investigation), the interpretation phase (interpretation), the guidance stage (intervention), and the assessment stage (inspection) [8]. The delivery phase is the first stage in the counseling process, this stage delivers the counselee in the counseling activity including an explanation of the purpose, objectives and time. The delivery stage is characterized by warm acceptance, permissiveness, non-blame, and full understanding of the counselee. This initial stage is crucial because if this stage is effective then the counselee will be more active in following the counseling process with optimal processes and results.

The second stage, assessment, is a phase that is analogous to a wilderness containing counselee problems, the main objective of the assessment stage is for the counselor to be able to understand the counselee completely. In the third stage, interpretation, the counselor develops a meaningful connection with the counselee's problem. The fourth stage is the coaching or guidance stage, which is the core of the counseling process. The coaching stage is concerned directly with efforts to resolve counselee problems and make progress with counselee selfdevelopment. This intervention phase also aims to create the expected changes as more consistent counselee behavior. The last stage is the assessment phase which aims to assess the process and the results of counseling, both ongoing and long-term.

Another theory on the implementation of individual counseling services, which includes three stages: first, the initial stage of counseling. This stage is also called the problem definition stage, because the goal is that the counselor and client can define the client's problems that are captured or selected from client issues or messages in the counseling dialogue. There are a few counseling techniques that must be in the early stages of counseling, namely: (1) attending. Good attending behavior is a combination of eyes, body language and client body language, so that it will facilitate the mentor to involve the client in conversation and openness. Another important technique is (2) empathy, which is the ability to feel what the client feels, feel and think with the client, and not for or about the client. Lastly, (3) reflection of feelings is the skill of the counselor to be able to reflect on the client's feelings [7].

An individual counselor needs to have good communication with the clients, and the first way to build communication in counseling is to build rapport. Individuals counseling means meeting a counselor with clients on an individual basis, where there is a relationship counseling nuanced rapport, and counselors strive to provide assistance for personal development of the client and the client can anticipate the problems they face [7]. Individual counseling is a special service in the face-to-face relationship between the counselor and the client to examine the problem and try to alleviate the problem with the client's own strengths. The individual counseling process in principle emphasizes how rapport between counselor and client rapport atmosphere is to build a relationship that is characterized by harmony, compatibility, and cooperation.

Rapport begins with agreement, liking and equality, if it has happened then a platonic fondness may arise between the counselor and counselee. In counseling relationships, the most important thing is to increase client confidence in the counselor [8]. In the counseling process, the involvement of the client is determined by the factor of self-disclosure before the counselor, so that the client will be open in expressing the client's problem and willing to be involved in counseling talks [7]. Communication between counselor and client will be easier if rapport has been formed. Rapport is a good relationship between counselor and counselee that shows optimal cooperation.

\section{METHODS}

This research uses a descriptive method, which is a method of analyzing and describing existing research data, which are associated with theories related to the problem that needs to be solved, in order to draw a conclusion. This research was conducted in the city of Banda Aceh. Data 
source sampling techniques in qualitative research are purposive and snowball, amounting to ten people. Data collection techniques are observation and interviews [9] of ten people. Data collection techniques are interviews and observation. In-depth interviews in general are the process of obtaining information for research purposes by means of a question-and-face interview between the interviewer and the respondent, with or without an interview guide, where the interviewer is involved in a relatively long social life [10]. Observation is a data collection technique that has specific characteristics when compared with other techniques, and observation is not limited to people but to other natural objects [11].

\section{RESULT AND DISCUSSION}

Based on the results, the majority of respondents who live in Aceh, do not realize that when they want to build rapport, they indirectly apply culture peumulia jame, in because culture peumulia jame is already very much a part of the Acehnese culture and community. Peumulia jame includes many different behaviors, such as accepting clients with open arms, treating clients with modest drinks and food, and in fact there are a few samples deliberately providing snacks for their clients when counseling. Also based on the results of the observations, it was found that the guidance and counseling room is designed in such a way that the client is comfortable. While the guidance and counseling teacher sits in an ordinary chair, they provide a special chair for the clients. Additionally, in the guidance and counseling room, there must be a drink that can be drunk by anyone who enters. From the results of the interviews, counselors are also indirectly applying the concept of peumulia jame, such as accepting clients with friendly smiles. This is the main key of peumulia jame, because it is the simple concept of how people are able to communicate simply through a smile when welcoming guests.

Based on this research and analysis of the data above, it can be claimed that most of the counselors who were interviewed for this study have adopted peumulia jame culture when building rapport in the counseling process. This is because peumulia jame culture is the local wisdom of Aceh.

\section{CONCLUSION}

The most basic behavior that illustrates peumulia jame is how the community is able to implement it simply by when welcome guests. If this cannot be implemented and shown to guests or visitors, other things will also be imperfect in the term Peumulia Jamee Adat Geutanyoe Aceh. Acehnese history states that based on its origin, the ethnic Acehnese are divided into four kawom or sukee (clans). This division began to be carried out during the Alaaidin reign of Sultan Al-Kahar (1530-1552). Individual counselors must have good communication with clients, and the first way to build good communication in counseling is firstly the development of rapport. Then, individual counseling is a meeting of counselors with individual clients, where counseling relationships have nuanced rapport, and counselors seek to provide assistance for the personal development of clients and to prepare clients to anticipate the problems they will face. If a counselor lives in Aceh, the counselor should develop rapport through applying Acehnese culture such as peumulia jame, so that the counseling process can proceed smoothly. Sometimes this process does not proceed smoothly due to the mixing of customary habits around with the implementation of counseling.

\section{ACKNOWLEDGMENT}

Thanks and appreciation to UPT. Lab Terpadu and LPPM Syiah Kuala University for funding this research through Syiah Kuala University Laboratory Grant Funds.

\section{REFERENCES}

[1] Sukardi, Dewa Ketut. (1983). Dasar-dasar Bimbingan Penyuluhan di Sekolah, Surabaya: Usaha Nasional.

[2] Darwis A. Soelaiman (2011). Kompilasi Adat Aceh. Banda Aceh: Pusat Studi Melayu Aceh (PUSMA).

[3] Ria Herlita (2014). Pesan Budaya Dalam Tari Ranup Lampuan Berdasarkan Tradisi Peumulia Jamee. Skripsi. Program Studi Sendratasik, FKIP. Unsyiah.

[4] Ensiklopedia Kebudayaan Aceh

[5] Mappiare, Andi. (2017). Meramu Model Konseling Berbasis Budaya Nusantara: KIPAS (Konseling Intensif Progresif Adaptif Struktur). Universitas Malang.

[6] Adhiputra, Anak Agung Ngurah. (2013). Konseling Lintas Budaya. Yogyakarta: Graha Ilmu.

[7] Willis S. Sofyan (2004) Konseling Individual Teori dan Praktek. CV Alfabeta.

[8] Prayitno dan Amti, E. 2004. Dasar-Dasar Bimbingan dan Konseling, Jakarta: Rineka Cipta.

[9] Sugiono. 2014. Memahami Penelitian Kualitatif . Penerbit Alfabeta, Bandung.

[10] Bungin, Burhan. 2011. Penelitian Kualitatif. Komunikasi, ekonomi, Kebijakan Publik, dan Ilmu Sosial Lainnya. Kencana Prenada Media Group; Jakarta.

[11] Sugiono. 2009. Metode Penelitian Pendidikaan Pendekatan Kuantitatifm Kualitatif dan R\&D. CV Albeta; Bandung. 